\title{
Detection of low-level parental somatic mosaicism for clinically relevant SNVs and indels identified in a large exome sequencing dataset
}

\author{
Daniel D. Domogala ${ }^{1,2}$, Tomasz Gambin ${ }^{1,3}$, Roni Zemet ${ }^{1}$, Chung Wah Wu ${ }^{1,4}$, Katharina V. Schulze ${ }^{1,4}$, \\ Yaping Yang ${ }^{5}$, Theresa A. Wilson ${ }^{1}$, Ido Machol ${ }^{4}$, Pengfei Liu ${ }^{1,4}$ and Paweł Stankiewicz ${ }^{1 *}$ (D)
}

\begin{abstract}
Background: Due to the limitations of the current routine diagnostic methods, low-level somatic mosaicism with variant allele fraction (VAF) $<10 \%$ is often undetected in clinical settings. To date, only a few studies have attempted to analyze tissue distribution of low-level parental mosaicism in a large clinical exome sequencing (ES) cohort.

Methods: Using a customized bioinformatics pipeline, we analyzed apparent de novo single-nucleotide variants or indels identified in the affected probands in ES trio data at Baylor Genetics clinical laboratories. Clinically relevant variants with VAFs between 30 and $70 \%$ in probands and lower than 10\% in one parent were studied. DNA samples extracted from saliva, buccal cells, redrawn peripheral blood, urine, hair follicles, and nail, representing all three germ layers, were tested using PCR amplicon next-generation sequencing (amplicon NGS) and droplet digital PCR (ddPCR).

Results: In a cohort of 592 clinical ES trios, we found 61 trios, each with one parent suspected of low-level mosaicism. In 21 parents, the variants were validated using amplicon NGS and seven of them by ddPCR in peripheral blood DNA samples. The parental VAFs in blood samples varied between 0.08 and $9 \%$. The distribution of VAFs in additional tissues ranged from $0.03 \%$ in hair follicles to $9 \%$ in re-drawn peripheral blood.

Conclusions: Our study illustrates the importance of analyzing ES data using sensitive computational and molecular methods for low-level parental somatic mosaicism for clinically relevant variants previously diagnosed in routine clinical diagnostics as apparent de novo.
\end{abstract}

Keywords: Clinical diagnostic testing, Mosaicism carrier, Recurrence risk, Rare variants, Mendelian genomics

\section{Introduction}

Somatic mosaicism occurs when a fraction of cells in the body contain a variant that arose as a result of a postzygotic mutation. For every cell mitotic division in an individual's life, one to three mutations occur; however, by using the germline [1], few of these mutations are passed on to an offspring. If a mutation arises within the first eight cell divisions of human embryonic development, it

*Correspondence: pawels@bcm.edu

${ }^{1}$ Department of Molecular and Human Genetics, Baylor College of Medicine, One Baylor Plaza, Houston, TX 77030, USA

Full list of author information is available at the end of the article can be present in both somatic cells and in the germline. Somatic mosaicism has been described in a wide variety of genetic disorders with all modes of inheritance and has been observed across different tissues [2-16]. Recent studies have shown that low-level somatic mosaic variants leading to neurodevelopmental disorders, congenital heart disease, and autism are more prevalent than previously thought [17-23].

It has been observed in parental blood samples that low-level $(<10 \%)$ somatic mosaicism may significantly increase the risk of passing pathogenic single-nucleotide variants (SNVs) or copy number variants (CNVs) to the original author(s) and the source, provide a link to the Creative Commons licence, and indicate if changes were made. The images or other third party material in this article are included in the article's Creative Commons licence, unless indicated otherwise in a credit line to the material. If material is not included in the article's Creative Commons licence and your intended use is not permitted by statutory regulation or exceeds the permitted use, you will need to obtain permission directly from the copyright holder. To view a copy of this licence, visit http://creativecommons.org/licenses/by/4.0/. The Creative Commons Public Domain Dedication waiver (http://creativeco mmons.org/publicdomain/zero/1.0/) applies to the data made available in this article, unless otherwise stated in a credit line to the data. 
offspring [24]. Variants present at low levels in an individual's cells can be challenging to detect by standard clinical techniques, e.g., chromosomal microarray analysis (CMA), exome sequencing (ES), or Sanger sequencing. Such variants are often interpreted as de novo in the affected offspring when not detected routinely in the parental samples [25]. Additionally, the majority of somatic mosaicism studies have primarily analyzed DNA extracted from whole blood samples without sampling other tissues, including germline. Of note, the levels of mosaicism may vary greatly in whole blood as a result of somatic clonal expansion, especially in subjects with advanced age [26]. Furthermore, recent work has shown that blood cell lineages branch off from other cell lineages early in embryogenesis and that certain bottlenecks in embryonic development lead to heterogeneity in genetic mosaicism in different regions of the brain $[27,28]$. Thus, it has been suggested that somatic mosaicism may not be measured in the most accurate fashion through sampling whole blood samples.

Recently, we have shown that variant allele fraction (VAF) in non-blood tissues such as the hair follicles, fibroblast, sputum, and buccal cells had higher VAF values than those in whole blood samples [29]. However, the number of analyzed samples was too low for statistical significance.

Here, we have queried the ES database at Baylor Genetics (BG) clinical genetics laboratory to identify parental low-level somatic mosaicism for clinically relevant singlenucleotide variants and small indels. ES data represent a highly enriched subset of clinically relevant variants that cause Mendelian disorders [30]. Sensitive molecular techniques were utilized to assess VAFs across different tissues in parents whose children have heterozygous or hemizygous clinically relevant SNVs or indels. The variation in VAFs across different somatic tissues and the difference between molecular techniques are discussed.

\section{Material and methods Sample collection}

From each of the ten parents enrolled in the study, peripheral blood in EDTA tubes, buccal swab, urine, saliva, hair, and nail samples were collected (Additional file 1: Table S1). At home, blood draws and sample collection and shipping were provided by ExamOne (Quest Diagnostics, Secaucus, NJ).

\section{In silico analyses}

A custom bioinformatics script described by Gambin et al. [29] was used to index the ES database at BG laboratories to select trios (DNA extracted from peripheral blood) where the proband had an apparent de novo and clinically relevant heterozygous or hemizygous SNV or small indel (Fig. 1). To select candidates variant calls in probands, erroneously called as heterozygous with a $\mathrm{VAF}>70 \%$ and $<30 \%$ and variants with ES read depth coverage below 20X were excluded. Criteria for candidate variants also included a MAF below $0.01 \%$ in Gno$\mathrm{mAD}$ (v2.1) and $<0.015 \%$ in the Baylor Hopkins Center for Mendelian Genomics (BHCMG) dataset. Variants located in repetitive and pseudogene genomic regions were filtered out. The analyses of the pileup data were performed using Samtools version 1.13 [31].

\section{Molecular analyses}

Following Sanger sequencing, validation of the putative parental somatic mosaic variants was performed using PCR amplicon-based next-generation sequencing (amplicon-NGS) (Cloudhealth Genomics, Shanghai, China) and droplet digital PCR (ddPCR). The experimental workflow to assess low-level somatic mosaic clinically relevant SNVs and small indels was largely based protocols developed by Liu et al. [32] for detection of somatic mosaic CNV deletions.

\section{DNA extraction}

DNA from peripheral blood was extracted using the Gentra Puregene Blood Kit (Qiagen, Germantown, MD, USA). The QIAamp DNA Investigator Kit (Qiagen) was used to extract DNA from at least five hair follicles and nail clippings from fingers or toes. The ORAcollect OGR-500 kit (DNA Genotek, Ottawa, Canada) and the ORAcollect OC-175 kit (DNA Genotek) were used to collect saliva and buccal cells, respectively. The prepITL2P (DNA Genotek) DNA extraction reagent was used to extract DNA from buccal cells and saliva. Urine was extracted within $24 \mathrm{~h}$ after collection using the QuickDNA Urine Kit (Zymo Research, Irvine, CA, USA). All procedures followed the manufacturer's protocols.

\section{Sanger sequencing}

Sanger sequencing was performed in probands where low-level mosaicism was suspected in a parent to ensure that proband and parental samples were not misidentified. In addition, Sanger sequencing was used as a validation of the primers created for use in for amplicon NGS sequencing to determine whether the variant of interest could be observed in the proband. If the variant of interest was observed in the middle of the Sanger sequencing output in both forward and reverse sequences in the proband sample, parental amplicons containing the region of interest were sequenced via PCR amplicon NGS. 


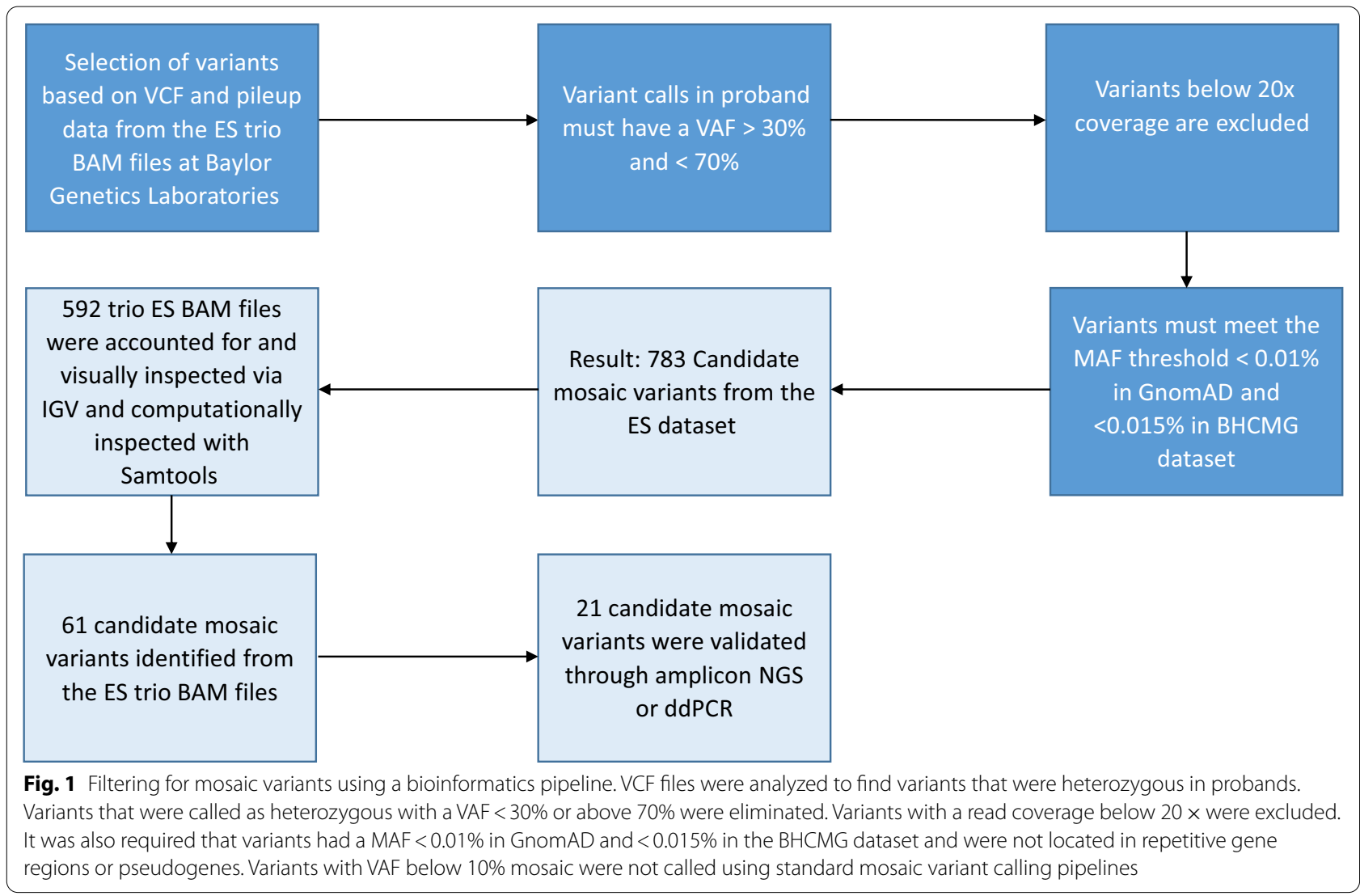

\section{Amplicon NGS}

The putative mosaic variants were targeted by PCR primers designed using the Primer3Plus tool. Candidate mosaic parental samples were amplified by PCR using Dreamtaq DNA polymerase (Thermofisher Scientific, Waltham, MA, USA). PCR products for each parental sample were purified using the QIAquick PCR Purification Kit (Qiagen) following the manufacturer's protocol. The concentration of the PCR products was quantified using the Qubit dsDNA BR Assay (ThermoFisher Scientific) by the Qubit 4 Flourometer (ThermoFisher Scientific). Purified PCR products of 150-280 bp in length were sequenced using the Illumina Novaseq platform (Illumina, San Diego, CA, USA) with 150-bp paired end reads at Cloud Health Genomics (Shanghai, China). Data were analyzed using BWA-mem, Integrative Genomics Viewer (IGV), and GATK HaplotypeCaller for putative mosaic indels. Custom scripts were written in R statistical programming language.

\section{ddPCR}

Droplet digital PCR primers and FAM and HEX probes were designed by and purchased from Integrative DNA Technologies (IDT) (Coralville, IA, USA). Reactions were prepared in $20 \mu \mathrm{l}$ aliquots, with $10 \mu \mathrm{l}$ of ddPCR supermix for probes (no dUTP), $0.5 \mu \mathrm{M}$ forward and reverse primer, 4 units of HindIII-HF (New England Biolabs, Ipswich, MA, USA), and 25 ng of DNA added. In every experiment, DNA from the proband's blood sample was used as a positive control, and unrelated wildtype DNA from an unrelated blood sample was used as a negative control. Dilution series of the variant of interest were performed using gBlocks (synthetically generated double-stranded DNA sequences that ranged in size from 250 to $500 \mathrm{bp}$ in length) (IDT) to determine the lowest level of detection for mosaic variants. These were subsequently used as positive and negative controls for validation of ddPCR assays, in SNV and small indel ddPCR assays. To test for contamination, a no-template control was used when testing each parental mosaic candidate.

\section{Results \\ Querying the BG ES database using a custom bioinformatics pipeline}

We initially selected 783 trios from the ES database at BG. For 191 (24\%) trios, the BAM files could not be retrieved for either parents or probands (Fig. 1). As a result, the BAM files of 592 trios were queried for 


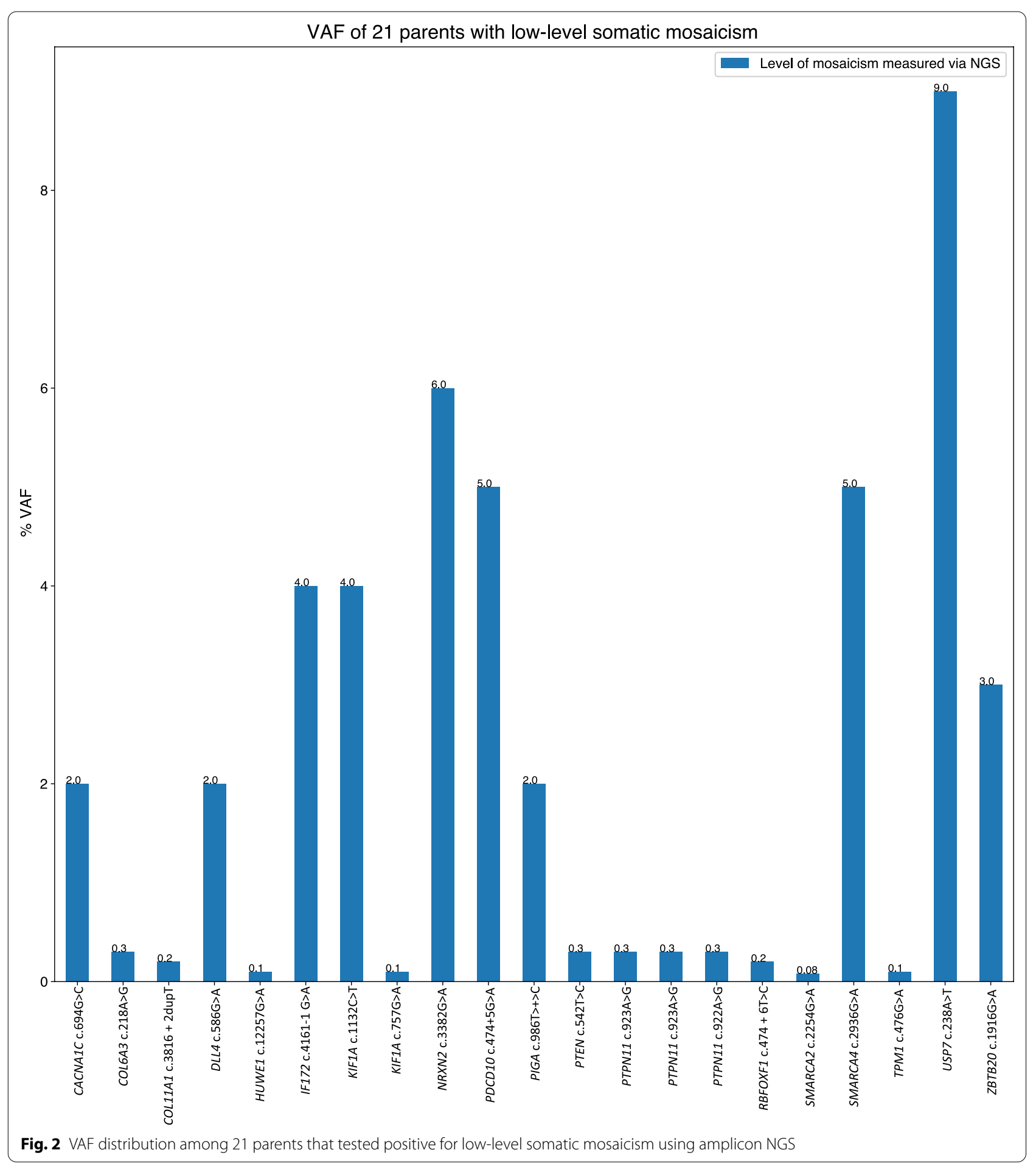

parental low-level somatic mosaicism using a custom bioinformatics pipeline (Fig. 1). Sixty-one (10.3\%) individuals were selected using computational methods based on the FracSampleswithAlt cutoff value of $<10 \%$ in the parental ES samples and visually screened using the IGV (Additional file 1: Fig. S1). Of the 61 mosaic candidates verified using computational methods, 21 (21/592, 3.5\%) tested positive for low-level mosaicism using amplicon NGS (Table 1, Figs. 1, 2, Additional file 1: Table S2, Fig. S1). In these 21 DNA samples, the 
Table 1 Characterization of 21 parental somatic mosaic variants identified in peripheral blood using clinical ES at BG

\begin{tabular}{|c|c|c|c|c|c|c|c|c|}
\hline Gene & Variant & $\begin{array}{l}\text { ACMG variant } \\
\text { classification }\end{array}$ & $\begin{array}{l}\text { Proband } \\
\text { phenotype }\end{array}$ & $\begin{array}{l}\text { Inheritance } \\
\text { mode }\end{array}$ & $\begin{array}{l}\text { Parental } \\
\text { mosaicism }\end{array}$ & $\begin{array}{l}\text { Level of } \\
\text { mosaicism in } \\
\text { ES (\%) }\end{array}$ & $\begin{array}{l}\text { Level of } \\
\text { mosaicism in } \\
\text { NGS }(\%)\end{array}$ & $\begin{array}{l}\text { Level of } \\
\text { mosaicism in } \\
\text { ddPCR }\end{array}$ \\
\hline CACNAIC & c.694G >C & VUS & $\begin{array}{l}\text { Timothy } \\
\text { Syndrome } \\
\text { [MIM:601005] }\end{array}$ & $A D$ & Maternal & 1 & 2 & NA \\
\hline COL6A3 & c. $218 \mathrm{~A}>\mathrm{G}$ & VUS & $\begin{array}{l}\text { Bethlem } \\
\text { myopathy } \\
\text { [MIM:58810] }\end{array}$ & $A D / A R$ & Maternal & 0.4 & 0.3 & NA \\
\hline COLI1AT & c.3816+ 2dupT & Pathogenic & $\begin{array}{l}\text { Stickler } \\
\text { Syndrome 2: } \\
\text { [MIM:604841] }\end{array}$ & $A D / A R$ & Maternal & 2.8 & $0.2(\mathrm{HC})$ & NA \\
\hline DLL4 & c. $586 \mathrm{G}>\mathrm{A}$ & $\begin{array}{l}\text { Likely patho- } \\
\text { genic }\end{array}$ & $\begin{array}{l}\text { Adams-Oliver } \\
\text { syndrome } \\
\text { [MIM:616589] }\end{array}$ & $A D$ & Paternal & 2 & 2 & $0.05 \%$ \\
\hline HUWE1 & c.12257G > A & $\begin{array}{l}\text { Likely patho- } \\
\text { genic }\end{array}$ & $\begin{array}{l}\text { Mental retarda- } \\
\text { tion, X-linked, } \\
\text { turner type } \\
\text { [MIM:30076] }\end{array}$ & $X \mathrm{~L}$ & Maternal & 0.3 & 0.1 & NA \\
\hline IFT172 & C. $4161-1 G>A$ & Pathogenic & $\begin{array}{l}\text { Retinitis } \\
\text { pigmentosa } \\
\text { [MIM:616394] }\end{array}$ & $A R$ & Paternal & 3 & 4 & $3.8 \%$ \\
\hline KIF1A & C. $1132 C>T$ & VUS & Polyhydramnios & $A D / A R$ & Maternal & 2 & 4 & $3.7 \%$ \\
\hline KIFIA & $c .757 G>A$ & Pathogenic & $\begin{array}{l}\text { Mental retarda- } \\
\text { tion, autosomal } \\
\text { dominant } 9 \\
\text { [MIM:614255] }\end{array}$ & $A D / A R$ & Paternal & 1 & 0.1 & NA \\
\hline NRXN2 & c. $3382 \mathrm{G}>\mathrm{A}$ & VUS & $\begin{array}{l}\text { Autism spec- } \\
\text { trum disorder }\end{array}$ & $A D$ & Maternal & 5 & 6 & $4.5 \%$ \\
\hline PDCD10 & $c .474+5 G>A$ & Pathogenic & $\begin{array}{l}\text { Cerebral } \\
\text { cavernous } \\
\text { malformations } \\
3 \text { [MIM:603285] }\end{array}$ & $A D$ & Paternal & 1 & 5 & NA \\
\hline PIGA & $\mathrm{c} .986 \mathrm{~T}>\mathrm{C}$ & $\begin{array}{l}\text { Likely patho- } \\
\text { genic }\end{array}$ & $\begin{array}{l}\text { Multiple } \\
\text { congenital } \\
\text { anomalies- } \\
\text { hypotonia-sei- } \\
\text { zures syndrome } \\
2 \text { [MIM:300868] }\end{array}$ & $X L R$ & Maternal & 2 & 2 & $1.83 \%$ \\
\hline PTEN & c. $542 T>C$ & Pathogenic & $\begin{array}{l}\text { Cowden } \\
\text { syndrome } 1 \\
\text { [MIM:158350] }\end{array}$ & $A D$ & Maternal & 2 & 0.3 & NA \\
\hline PTPN11 & $c .923 \mathrm{~A}>\mathrm{G}$ & Pathogenic & $\begin{array}{l}\text { Noonan } \\
\text { syndrome } 1 \\
\text { [MIM:163950] }\end{array}$ & $A D$ & Maternal & 1 & 0.3 & NA \\
\hline PTPN11 & $c .923 A>G$ & Pathogenic & $\begin{array}{l}\text { Noonan } \\
\text { syndrome } 1 \\
\text { [MIM:163950] }\end{array}$ & $A D$ & Maternal & 1 & 0.3 & NA \\
\hline PTPN11 & c. $922 A>G$ & Pathogenic & $\begin{array}{l}\text { Noonan } \\
\text { syndrome } 1 \\
\text { [MIM:163950] }\end{array}$ & $A D$ & Maternal & 1 & 0.3 & NA \\
\hline RBFOX1 & $c .474+6 \mathrm{~T}>\mathrm{C}$ & VUS & $\begin{array}{l}\text { Autism spec- } \\
\text { trum disorder }\end{array}$ & $A D$ & Paternal & 1 & 0.2 & NA \\
\hline SMARCA2 & c. $2254 \mathrm{G}>\mathrm{A}$ & $\begin{array}{l}\text { Likely patho- } \\
\text { genic }\end{array}$ & $\begin{array}{l}\text { Nicolaides-Bara- } \\
\text { ister syndrome } \\
\text { [MIM:601358] }\end{array}$ & $A D$ & Paternal & 1 & 0.08 & NA \\
\hline SMARCA4 & c. $2936 \mathrm{G}>\mathrm{A}$ & Pathogenic & $\begin{array}{l}\text { Coffin Siri syn- } \\
\text { drome } 4 \text { [MIM: } \\
614609]\end{array}$ & $A D$ & Paternal & 4 & 5 & $4.76 \%$ \\
\hline
\end{tabular}


Table 1 (continued)

\begin{tabular}{|c|c|c|c|c|c|c|c|c|}
\hline Gene & Variant & $\begin{array}{l}\text { ACMG variant } \\
\text { classification }\end{array}$ & $\begin{array}{l}\text { Proband } \\
\text { phenotype }\end{array}$ & $\begin{array}{l}\text { Inheritance } \\
\text { mode }\end{array}$ & $\begin{array}{l}\text { Parental } \\
\text { mosaicism }\end{array}$ & $\begin{array}{l}\text { Level of } \\
\text { mosaicism in } \\
\text { ES (\%) }\end{array}$ & $\begin{array}{l}\text { Level of } \\
\text { mosaicism in } \\
\text { NGS }(\%)\end{array}$ & $\begin{array}{l}\text { Level of } \\
\text { mosaicism in } \\
\text { ddPCR }\end{array}$ \\
\hline TPM1 & c. $475 \mathrm{G}>\mathrm{A}$ & $\begin{array}{l}\text { Likely patho- } \\
\text { genic }\end{array}$ & $\begin{array}{l}\text { Cardio- } \\
\text { myopathy } \\
\text { [MIM:115196] }\end{array}$ & $A D$ & Paternal & 2 & 0.1 & NA \\
\hline USP7 & $c .238 \mathrm{~A}>\mathrm{T}$ & $\begin{array}{l}\text { Likely patho- } \\
\text { genic }\end{array}$ & $\begin{array}{l}\text { Intellectual } \\
\text { disability } \\
\text { and autism } \\
\text { spectrum } \\
\text { disorder [PMID: } \\
\text { 26365382] }\end{array}$ & $A D$ & Maternal & 3 & 9 & 4.13 \\
\hline ZBTB2O & c.1916G > A & $\begin{array}{l}\text { Likely patho- } \\
\text { genic }\end{array}$ & $\begin{array}{l}\text { Primrose } \\
\text { syndrome } \\
\text { [MIM:259050] }\end{array}$ & $A D$ & Paternal & 1 & 3 & NA \\
\hline
\end{tabular}

$A D$ autosomal dominant, $A R$ autosomal recessive, HC GATK haplotype caller, NA none accountable, VUS variant of unknown significance, $X L R$ X-linked recessive

Table 2 Ten parents suspected of low-level somatic mosaicism enrolled in this study

\begin{tabular}{lllll}
\hline Parent & Gene & Variant & $\begin{array}{l}\text { Mosaic } \\
\text { using NGS }\end{array}$ & $\begin{array}{l}\text { Tissues } \\
\text { received }\end{array}$ \\
\hline M1 & USP7 & c.238A $>$ T & Yes & Yes \\
M2 & PTPN11 & c.923A > G & Yes & Yes \\
M3 & PTPN11 & c.923A > G & Yes & Yes \\
M4 & COL11A1 & c.3816+2dupT & Yes & Yes \\
M5 & CACNA1C & c.694G >C & Yes & Yes \\
M6 & SYNGAP1 & c.1782dupC & No & Yes \\
M7 & SYNGAP1 & c.654_655delCT & No & Yes \\
M8 & PUF60 & c.628C $>$ T & No & Yes \\
F1 & STXBP1 & c.1099C $>$ T & No & No \\
F2 & NEDD4L & c.814-6T $>$ A & No & Yes \\
\hline
\end{tabular}

$M$ mother, $F$ father

ratio of the clinically relevant variants had a paternal to maternal ratio of 9:12 (Additional file 1: Fig. S2).

\section{Molecular analyses}

One parent was validated molecularly as being lowlevel mosaic for a clinically relevant variant that was previously diagnosed as apparent de novo in 3.4\% (21/592) of trios. Out of ten families consisting of eight mothers and two fathers enrolled in the study, we have obtained different tissue samples from nine families, five of which tested molecularly positive for low-level mosaicism (Tables 2, 3).

\section{Amplicon NGS}

Twenty-one (34.4\%) out of 61 blood samples with VAFs in ES data ranging from 0.3 to $5 \%$ (median 1.5\%) tested positive for parental somatic mosaicism using amplicon NGS. VAFs ranged from $0.08 \%$ to $11.0 \%$ (median $0.3 \%$ )
(Table 1). The average read depth at the variant position in question was $621,899 \times$.

\section{Droplet digital PCR validation}

Dilution series were performed using gBlocks controls and artificial or mock low-level mosaics that established a lower level of detection of 0.5 VAF percentage to establish the limit of detection of low-level mosaic variants using ddPCR (Additional file 1: Fig. S3).

\section{Level of mosaicism in peripheral blood}

VAF percentages for low-level mosaic variants in blood tested using ddPCR ranged between 0.05 and $4.76 \%$ (median 3.7\%) (Table 1). The highest VAFs of $4.76 \%$ for the c.2936G > A variant in SMARCA4 and $4.1 \%$ for the c.3382G > A variant in the NRXN2 gene were measured using ddPCR in peripheral blood. Accordingly, the highest VAFs measured by amplicon NGS were $5 \%$ for the c. $2936 \mathrm{G}>\mathrm{A}$ variant in SMARCA4 and $6 \%$ for the c.3382G > A variant in the NRXN2 gene. The c. $1132 \mathrm{C}>\mathrm{T}$ and c.4161-1G>A variants in KIF1A and IFT172 had VAFs of $3.7 \%$ and $3.8 \%$, respectively, when measured using ddPCR in the blood. The VAF percentage of $4.0 \%$ was observed for both variants when amplicon NGS was performed. The lower end of VAF measurements using ddPCR was observed for the c.986T $>$ C and c.586G $>$ A variants in PIGA and DLL4 with VAFs of $1.8 \%$ and $0.05 \%$, respectively. The VAFs measured using amplicon NGS were $2.0 \%$ for both PIGA c. $986 \mathrm{~T}>\mathrm{C}$ and DLL4 c.586G > A variants.

Of note, 3 out of 21 (14\%) unrelated parents were found to be candidate somatic mosaic for the PTPN11 pathogenic variants causative for Noonan syndrome, with an average VAF percentage measured by amplicon NGS of $0.3 \%$. 


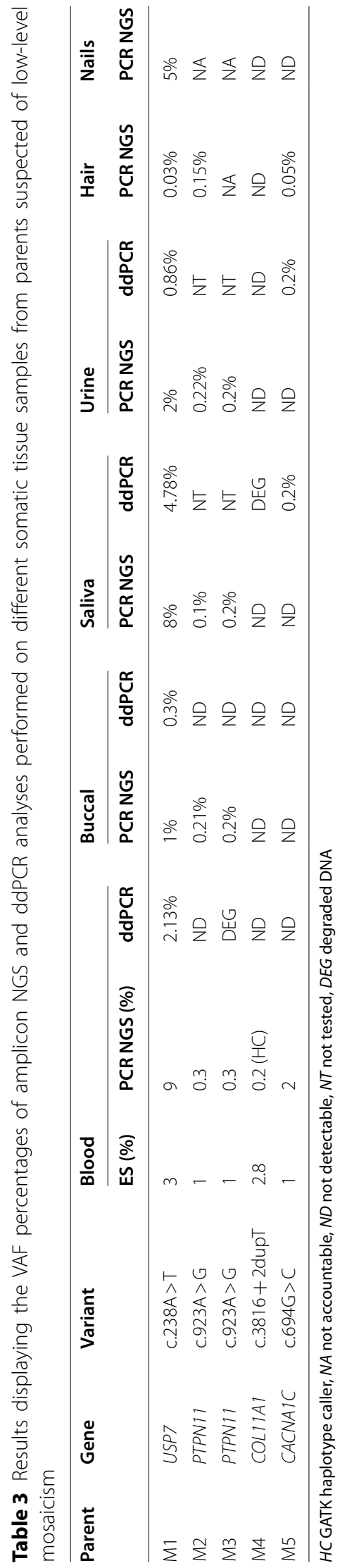


The largest difference observed in the level of mosaicism over time in blood leukocytes was observed in parent M1 where the differences in VAF decreased by $2 \%$ (Additional file 1: Table S3). No other changes in VAF in DNA extracted from blood leukocytes were observed across other samples.

\section{Comparison of low-level mosaicism across different somatic tissues}

DNA extracted from blood leukocytes had the highest detected VAF compared with other tissues when mosaicism was assessed using amplicon NGS. The mean and median VAF differences between measurements taken using amplicon NGS and ddPCR were $2.99 \%$ and $2.18 \%$, respectively. Mosaicism level measured by amplicon NGS in blood leukocytes $\leq 2.0 \%$ was not detected by ddPCR.

Of five families enrolled, low-level mosaicism was detected in all sampled tissues in only one mother (M1) with the c.238A > T likely pathogenic variant in the USP7 gene through the use of amplicon NGS and ddPCR. Parent M1 with a VAF percentage measured by ddPCR in peripheral blood leukocytes of $2.13 \%$ had the highest VAF measured by ddPCR in the saliva (4.78\%) and the lowest VAF in a buccal swab sample (0.3\%) (Additional file 1: Fig. S4). The variance in the VAFs across tissues measured by amplicon NGS was $14.1 \%$, the variance for M1 was $2.89 \%$. In $60 \%(3 / 5)$ of parents, low-level mosaicism could be detected in peripheral blood leukocytes using amplicon NGS, but was undetectable by ddPCR. In subject M5, mosaicism was not detected in the blood using ddPCR, but was detected at a VAF of $0.2 \%$ in the saliva and urine samples.

\section{Inheritance pattern}

Notably, 71\% (15/21) of low-level somatic mosaic variants were in autosomal dominant (AD) trait genes, $14 \%(3 / 21)$ in autosomal dominant/autosomal recessive disease (AD/ AR) trait genes, $9 \%(2 / 21)$ in X-linked trait genes, and $4 \%$ $(1 / 21)$ in AR trait genes (Additional file 1: Fig. S5).

\section{Discussion}

Our recent study [29] of 102 parents with candidate mosaic variants validated using amplicon NGS, ddPCR, or blocker displacement amplification (BDA) [33] revealed 27 (26.4\%) as low-level mosaic (VAF percentage between 1 and 10\%) or very low-level mosaic (VAF percentage $<1 \%$ ). Here, we have sought to expand the sample size of tissues from parents with suspected low-level mosaic clinically relevant SNVs or indels to determine whether whole peripheral blood is the optimal tissue to assess low-level parental somatic mosaicism. Using a customized bioinformatics pipeline, we have queried the ES database and found that approximately $3.4 \%$ of clinically relevant variants diagnosed as apparent de novo events are in fact low-level parental somatic mosaicism. This study is unique in that it is restricted to clinically relevant variants identified in a large ES dataset that meet the ACMG criteria of being pathogenic, likely pathogenic, or variant of unknown significance [34].

To date, most of the somatic mosaic variants that result in a single damaging event with a large phenotypic effect have been reported to be more common in neurodevelopmental disorders with an AD inheritance pattern [14]. Consistent with these findings, we have observed that neurodevelopmental disorders due to variants in $\mathrm{AD}$ trait genes, including cerebral cortical malformations, autism spectrum disorder [19], and epileptic encephalopathy [3], were in a large proportion of the study cohort (Additional file 1: Table S2). However, this apparent enrichment can be reflective of these phenotypes being primarily referred for trio ES testing at BG. Mosaicism in traits that are AR is rare and requires that a variant allele is inherited from one parent in addition to a de novo event occurring [35, 36].

There was no disproportionate difference between the number of clinically relevant low-level mosaic variants inherited paternally $(42 \%)$ or maternally $(57 \%)$. The observed ratio close to 1:1 has been observed in previous studies of somatic mosaicism [37] and contrasts with gonadal mosaicism which is skewed to paternal inheritance due to high number of divisions occurring during spermatogenesis [38].

In some disorders, it is necessary to sample for mosaicism in tissues other than blood. For example, in patients with Pallister-Killian syndrome, patch-like patterns occurring in skin may need to be sampled for tetrasomy of isochromosome 12p [39] due to mosaicism being limited at that site. In addition, clonal expansion of peripheral blood leukocytes may lead to an erroneous conclusion of an increased level of mosaicism over time. Therefore, using more sensitive and precise molecular techniques, we have measured variation in the level of mosaicism also across different somatic tissues. Analysis of low-level mosaic clinically relevant variants in five families revealed variation in VAFs across blood, buccal, saliva, urine, hair, and nails. Fluctuations in VAF percentages across all tissues samples were observed only in one mother (M1). The c.238A > T likely pathogenic variant in the USP7 gene was present at the highest VAF in samples taken from the mesoderm germ layers (blood, saliva). Samples taken from tissues in the other germ layers were observed to have more variable VAFs, with an observable variation in the VAFs in samples taken from the hair and nails which represent the ectoderm germ layer. Hair and 
nails tissue samples had the most outlying VAFs, which has been observed previously [29].

Hair is comprised of $95 \%$ protein and yields a small amount of DNA template which could possibly lead to a variable assessment of somatic mosaicism [40]. Extraction of high quality genomic DNA from nails can be hindered when DNA is fragmented during the keratinization process that occurs during cellular growth [41].

In three parents with low-level mosaicism, the clinically relevant variant of interest was detected in urine. Urinary sediment can have trace amounts of leukocytes, erythrocytes, and urinary epithelial cells [42]. Assessment of the degree of variation in VAF for clinically relevant low-level mosaic variants across different tissues can be useful to clinicians to determine at what stage of embryogenesis the variant arose. This in turn may help to determine whether they might be present in germline and transmitted to progeny.

Use of NGS (at an average coverage depth of $621,899 \times$ ) enabled the detection of mosaic variants with VAFs that would have been missed using standard clinical methods. Of note, sequencing at a depth of over $2000 \times$ read coverage does not provide additional information even in recent NGS platforms such as Illumina Novaseq. The error rate in amplicon NGS depends on several factors, e.g., DNA polymerase, NGS workflow used, sample handling, and the type of PCR enrichment performed, not allowing for substantial improvement in the sensitivity rate. Gambin et al. [29] observed that detection of VAFs in NGS below $1 \%$ could not be verified using ddPCR. ddPCR has been reported to have a theoretical VAF sensitivity rate of $0.001 \%$, and our previous ddPCR experiments have been able to detect somatic mosaic variants in the FOXF1 gene at a cutoff sensitivity VAF of $0.1 \%$ [43-45]. We have utilized ddPCR in seven parents. A discrepancy between these methods was observed in four cases. VAFs below $2 \%$ detected using NGS in peripheral blood leukocytes were not identified using ddPCR. Moreover, the same variant c.923A $>$ G in PTPN11, identified as $0.3 \%$ mosaic in amplicon NGS studies in three unrelated parents (Table 1), but was not verified by ddPCR across different tissues in parents M2 and M3 (Tables 2, 3 ), indicating that it may represent a technical artifact. In parent M5, 0.2\% mosaicism for the c.694G $>C$ variant in CACNA1C was detected using ddPCR in the saliva and urine samples, but it was not found using amplicon NGS. These results illustrate the value of validation using multiple sensitive molecular techniques such as ddPCR and amplicon NGS for clinically relevant low-level mosaic variants. Additionally, these results provide further evidence for genetic counselors that sensitive molecular techniques such as PCR amplicon NGS or ddPCR may be used in detection of low-level mosaic clinically relevant variants that are diagnosed as apparent de novo.

Recently, novel techniques for detecting and precisely measuring low-level somatic mosaicism even below $0.1 \%$ have been described. BDA can reliably detect VAFs even below $0.1 \%$ [46]. MIPP-Seq that utilizes unique molecular identifiers to increase assay sensitivity can be used for measuring VAFs for SNVs and indels as low as $0.025 \%$ [47]. The use of a low number of PCR cycles along with the use of multiple independent primers that cover the variant region leads to less allelic dropout. Methods such as these can be used as a means of orthogonal validation in addition to PCR amplicon NGS and ddPCR, to determine if a low-level mosaic variant with a $\mathrm{VAF}<2 \%$ is an artifact. Molecular barcoding techniques such as MIPPSeq could be utilized to validate low-level somatic mosaic variants including SNVs, CNVs, and indels. However, these methods can be cost prohibitive to implement.

The vast majority of the variants identified here as low-level mosaic were SNVs and only a few indels. This bias may result from low-level mosaic indels presenting a detection challenge both bioinformatically in analyzing NGS data and for designing FAM and HEX probes for ddPCR. Reads where indels occur are often filtered out during sequence alignment, which may lead to erroneous indel calling. Secondly, overlapping reads are more difficult to align and may consequently be mapped with incorporated mismatches [48]. In a mother (M5) with a COL11A1 c.3816+2dupT pathogenic variant, the mosaic insertion could only be detected in the blood through use of GATK haplotype caller, and was not found in other tissues. This finding was unexpected as the insertion was observed in $2.8 \%$ of reads generated from ES. Previous studies have found that indels occurring in the human genome are missed at a rate of $10-35 \%$ [49]. However, the rate that low-level somatic mosaic indels present in the human genome could be missed is more than $35 \%$ of the time.

\section{Conclusions}

The rate of mosaicism observed in the ES dataset (3.4\%) corroborates the previous studies. The differences in VAF percentages among sampled non-blood tissues add to the notion that other tissues may be informative in detection and quantification of low-level somatic mosaicism. Low-level somatic mosaic indels are difficult to detect due to filtering and mapping challenges. Use of multiple sensitive molecular techniques in addition to assessing multiple tissues for clinically relevant variants should be considered by investigators and clinicians for validation of low-level parental somatic mosaicism. 
These practices would facilitate more accurate assessment of recurrence risk.

\author{
Abbreviations \\ amplicon NGS: PCR amplicon next-generation sequencing; BCM: Baylor \\ College of Medicine; BDA: Blocker displacement amplification; BG: Baylor \\ genetics; BHCMG: Baylor Hopkins Center for Mendelian Genomics; CNV: Copy \\ number variant; ddPCR: Droplet digital PCR; ES: Exome sequencing; SNV: \\ Single-nucleotide variant; VAF: Variant allele fraction.
}

\section{Supplementary Information}

The online version contains supplementary material available at https://doi. org/10.1186/s40246-021-00369-6.

Additional file 1. Supplementary Tables S1-S3 and Figures S1-S5.

\section{Acknowledgements}

We are thankful to families who provided tissue samples for this research work. We thank Christopher Grochowski for helpful discussion.

\section{Authors' contributions}

DDD, CWW, IM, and PL collected the ES data, DDD, TG, RZ, KWS, YY, PL, and PS analyzed and interpreted the results, TAW contacted the families, DDD wrote the manuscript, and TG and PS designed the study concept, interpreted the results, and critically revised the final version of the article. All authors read and approved the final manuscript.

\section{Funding}

This study is supported by the US National Institute of Health (NIH): Eunice Kennedy Shriver National Institute of Child Health \& Human Development (NICHD) Grant R01HD087292 to Dr. Stankiewicz.

\section{Availability of data and materials}

Please contact the author for data requests.

\section{Declarations}

\section{Ethics approval and consent to participate}

All analyzed samples were de-identified, and research was approved under the Institutional Review Board for Human Subject Research at Baylor College of Medicine under the protocols $\mathrm{H}-41191$ and $\mathrm{H}-46683$.

\section{Consent for publication}

Written consent to study different somatic tissues was obtained from ten individuals.

\section{Competing interests}

The Department of Molecular and Human Genetics at Baylor College of Medicine derives revenue from clinical ES offered by the BG Laboratories. Authors who are faculty members in the Department of Molecular and Human Genetics at BCM are identified as such in the affiliation section. The remaining authors declare that they have no competing interests.

\section{Author details \\ 'Department of Molecular and Human Genetics, Baylor College of Medicine, One Baylor Plaza, Houston, TX 77030, USA. ${ }^{2}$ Graduate Program in Diagnostic Genetics, School of Health Professions, University of Texas at MD Ander- son, Houston, TX, USA. ${ }^{3}$ Institute of Computer Science, Warsaw University of Technology, Warsaw, Poland. ${ }^{4}$ Baylor Genetics, Houston, TX, USA. ${ }^{5}$ AiLife Diagnostics, 1920 Country Place Pkwy Suite 100, Pearland, TX, USA.}

Received: 27 October 2021 Accepted: 27 November 2021

Published online: 20 December 2021

\section{References}

1. Lupski JR. Genome mosaicism—one human, multiple genomes. Science. 2013;341(6144):358-9.

2. Biesecker LG, Spinner NB. A genomic view of mosaicism and human disease. Nat Rev Genet. 2013;14(5):307-20.

3. Myers CT, Hollingsworth G, Muir AM, Schneider AL, Thuesmunn Z, Knupp A, et al. Parental mosaicism in "de novo" epileptic encephalopathies. N Engl J Med. 2018;378(17):1646.

4. Goriely A, Lord H, Lim J, Johnson D, Lester T, Firth HV, et al. Germline and somatic mosaicism for FGFR2 mutation in the mother of a child with Crouzon syndrome: implications for genetic testing in "paternal ageeffect" syndromes. Am J Med Genet Part A. 2010;152(8):2067-73.

5. Boone PM, Bacino CA, Shaw CA, Eng PA, Hixson PM, Pursley AN, et al. Detection of clinically relevant exonic copy-number changes by array CGH. Hum Mutat. 2010;31(12):1326-42.

6. Bartnik M, Derwińska K, Gos M, Obersztyn E, Kołodziejska KE, Erez A, et al. Early-onset seizures due to mosaic exonic deletions of CDKL5 in a male and two females. Genet Med. 2011;13(5):447-52.

7. Poduri A, Evrony GD, Cai X, Walsh CA. Somatic mutation, genomic variation, and neurological disease. Science. 2013;341(6141):1237758.

8. King DA, Jones WD, Crow YJ, Dominiczak AF, Foster NA, Gaunt TR, et al. Mosaic structural variation in children with developmental disorders. Hum Mol Genet. 2015;24(10):2733-45.

9. Xin B, Cruz Marino T, Szekely J, Leblanc J, Cechner K, Sency V, et al. Novel DNMT3A germline mutations are associated with inherited TattonBrown-Rahman syndrome. Clin Genet. 2017;91(4):623-8.

10. Stosser MB, Lindy AS, Butler E, Retterer K, Piccirillo-Stosser CM, Richard G, McKnight DA. High frequency of mosaic pathogenic variants in genes causing epilepsy-related neurodevelopmental disorders. Genet Med. 2018;20(4):403-10.

11. Ansari M, Poke G, Ferry Q, Williamson K, Aldridge R, Meynert AM, et al. Genetic heterogeneity in Cornelia de Lange syndrome (CdLS) and CdLSlike phenotypes with observed and predicted levels of mosaicism. J Med Genet. 2014;51(10):659-68.

12. Conlin LK, Thiel BD, Bonnemann CG, Medne L, Ernst LM, Zackai EH, et al. Mechanisms of mosaicism, chimerism and uniparental disomy identified by single nucleotide polymorphism array analysis. Hum Mol Genet. 2010;19(7):1263-75

13. Serra EG, Schwerd T, Moutsianas L, Cavounidis A, Fachal L, Pandey S, et al. Somatic mosaicism and common genetic variation contribute to the risk of very-early-onset inflammatory bowel disease. Nat Commun. 2020;11(1):1-5.

14. Cao Y, Tokita MJ, Chen ES, Ghosh R, Chen T, Feng Y, et al. A clinical survey of mosaic single nucleotide variants in disease-causing genes detected by exome sequencing. Genome Med. 2019;11(1):1-1.

15. Sano S, Wang Y, Walsh K. Somatic mosaicism: implications for the cardiovascular system. Eur Heart J. 2020;41(30):2904-7.

16. Morales F, Vásquez M, Corrales E, Vindas-Smith R, Santamaría-Ulloa C, Zhang B, et al. Longitudinal increases in somatic mosaicism of the expanded CTG repeat in myotonic dystrophy type 1 are associated with variation in age-at-onset. Hum Mol Genet. 2020;29(15):2496-507.

17. Shu L, Zhang Q, Tian Q, Yang S, Peng X, Mao X, et al. Parental mosaicism in de novo neurodevelopmental diseases. Am J Med Genet Part A. 2021;185(7):2119-25.

18. Manheimer KB, Richter F, Edelmann LJ, D'Souza SL, Shi L, Shen Y, et al. Robust identification of mosaic variants in congenital heart disease. Hum Genet. 2018;137(2):183-93.

19. Breuss MW, Antaki D, George RD, Kleiber M, James KN, Ball LL, et al. Autism risk in offspring can be assessed through quantification of male sperm mosaicism. Nat Med. 2020;26(1):143-50.

20. Lim ET, Uddin M, De Rubeis S, Chan Y, Kamumbu AS, Zhang X, et al. Rates, distribution and implications of postzygotic mosaic mutations in autism spectrum disorder. Nat Neurosci. 2017;20(9):1217-24.

21. Freed D, Pevsner J. The contribution of mosaic variants to autism spectrum disorder. PLoS Genet. 2016;12(9):e1006245.

22. Jónsson H, Sulem P, Arnadottir GA, Pálsson G, Eggertsson HP, Kristmundsdottir $\mathrm{S}$, et al. Multiple transmissions of de novo mutations in families. Nat Genet. 2018:50(12):1674-80.

23. Jonsson H, Magnusdottir E, Eggertsson HP, Stefansson OA, Arnadottir GA, Eiriksson $O$, et al. Differences between germline genomes of monozygotic twins. Nat Genet. 2021;53(1):27-34. 
24. King DA, Sifrim A, Fitzgerald TW, Rahbari R, Hobson E, Homfray T, et al. Detection of structural mosaicism from targeted and whole-genome sequencing data. Genome Res. 2017;27(10):1704-14.

25. Wright CF, Prigmore E, Rajan D, Handsaker J, McRae J, Kaplanis J, et al. Clinically-relevant postzygotic mosaicism in parents and children with developmental disorders in trio exome sequencing data. Nat Commun. 2019;10(1):1-1.

26. Shlush LI. Age-related clonal hematopoiesis. Blood. 2018;131(5):496-504.

27. Park S, Mali NM, Kim R, Choi JW, Lee J, Lim J, et al. Clonal dynamics in early human embryogenesis inferred from somatic mutation. Nature. 2021;597(7876):393-7.

28. Coorens TH, Moore L, Robinson PS, Sanghvi R, Christopher J, Hewinson J, et al. Extensive phylogenies of human development inferred from somatic mutations. Nature. 2021;597(7876):387-92.

29. Gambin T, Liu Q, Karolak JA, Grochowski CM, Xie NG, Wu LR, et al. Low-level parental somatic mosaic SNVs in exomes from a large cohort of trios with diverse suspected Mendelian conditions. Genet Med. 2020;22(11):1768-76.

30. Bamshad MJ, Ng SB, Bigham AW, Tabor HK, Emond MJ, Nickerson DA, Shendure J. Exome sequencing as a tool for Mendelian disease gene discovery. Nat Rev Genet. 2011;12(11):745-55.

31. Danecek P, Bonfield JK, Liddle J, Marshall J, Ohan V, Pollard MO, et al. Twelve years of SAMtools and BCFtools. Gigascience. 2021;10(2):giab008.

32. Liu Q, Grochowski CM, Bi W, Lupski JR, Stankiewicz P. Quantitative assessment of parental somatic mosaicism for copy-number variant (CNV) deletions. Curr Protoc Hum Genet. 2020;106(1):e99.

33. Wu LR, Chen SX, Wu Y, Patel AA, Zhang DY. Multiplexed enrichment of rare DNA variants via sequence-selective and temperature-robust amplification. Nat Biomed Eng. 2017;1(9):714-23.

34. Richards S, Aziz N, Bale S, Bick D, Das S, Gastier-Foster J, et al. Standards and guidelines for the interpretation of sequence variants: a joint consensus recommendation of the American College of Medical Genetics and Genomics and the Association for Molecular Pathology. Genet Med. 2015;17(5):405-23.

35. Campbell IM, Shaw CA, Stankiewicz P, Lupski JR. Somatic mosaicism: implications for disease and transmission genetics. Trends Genet. 2015;31(7):382-92.

36. Rodin RE, Walsh CA. Somatic mutation in pediatric neurological diseases. Pediatr Neurol. 2018;87:20-2.

37. Rahbari R, Wuster A, Lindsay SJ, Hardwick RJ, Alexandrov LB, Al Turki S, et al. Timing, rates and spectra of human germline mutation. Nat Genet. 2016;48(2):126-33.

38. Qin J, Calabrese P, Tiemann-Boege I, Shinde DN, Yoon SR, Gelfand D, et al. The molecular anatomy of spontaneous germline mutations in human testes. PLoS Biol. 2007;5(9):e224.

39. Choo S, Teo SH, Tan M, Yong MH, Ho LY. Tissue-limited mosaicism in Pallister-Killian syndrome - a Case in Point. J Perinatol. 2002;22(5):420-3.

40. Catlin LA, Chou RM, Goecker ZC, Mullins LA, Silva DS, Spurbeck RR, et al. Demonstration of a mitochondrial DNA-compatible workflow for genetically variant peptide identification from human hair samples. Forensic Sci Int Genet. 2019;43:102148.

41. Hogervorst JG, Godschalk RW, van den Brandt PA, Weijenberg MP, Verhage $B A$, Jonkers $L$, et al. DNA from nails for genetic analyses in large-scale epidemiologic studies. Cancer Epidemiol Biomark Prev. 2014;23(12):2703-12.

42. Kunishima S, Kitamura K, Matsumoto T, Sekine T, Saito H. Somatic mosaicism in MYH 9 disorders: the need to carefully evaluate apparently healthy parents. Br J Haematol. 2014;165(6):885-7.

43. Hindson BJ, Ness KD, Masquelier DA, Belgrader P, Heredia NJ, Makarewicz AJ, et al. High-throughput droplet digital PCR system for absolute quantitation of DNA copy number. Anal Chem. 2011;83(22):8604-10.

44. Forthun RB, Hovland R, Schuster C, Puntervoll H, Brodal HP, Namløs $H M$, et al. ctDNA detected by ddPCR reveals changes in tumour load in metastatic malignant melanoma treated with bevacizumab. Sci Rep. 2019;9(1):1-5

45. Karolak JA, Liu Q, Xie NG, Wu LR, Rocha G, Fernandes S, et al. Highly sensitive blocker displacement amplification and droplet digital PCR reveal low-level parental FOXF1 somatic mosaicism in families with alveolar capillary dysplasia with misalignment of pulmonary veins. J Molec Diagn. 2020;22(4):447-56.
46. Ma X, Shao Y, Tian L, Flasch DA, Mulder HL, Edmonson MN, et al. Analysis of error profiles in deep next-generation sequencing data. Genome Biol. 2019:20(1):1-5

47. Doan RN, Miller MB, Kim SN, Rodin RE, Ganz J, Bizzotto S, et al. MIPP-Seq: ultra-sensitive rapid detection and validation of low-frequency mosaic mutations. BMC Med Genomics. 2021;14(1):1-3.

48. Narzisi G, O'rawe JA, lossifov I, Fang H, Lee YH, Wang Z, et al. Accurate de novo and transmitted indel detection in exome-capture data using microassembly. Nat Methods. 2014;11(10):1033-6.

49. Mullaney JM, Mills RE, Pittard WS, Devine SE. Small insertions and deletions (INDELs) in human genomes. Hum Molec Genet. 2010;19(R2):R131-6.

\section{Publisher's Note}

Springer Nature remains neutral with regard to jurisdictional claims in published maps and institutional affiliations.
Ready to submit your research? Choose BMC and benefit from:

- fast, convenient online submission

- thorough peer review by experienced researchers in your field

- rapid publication on acceptance

- support for research data, including large and complex data types

- gold Open Access which fosters wider collaboration and increased citations

- maximum visibility for your research: over $100 \mathrm{M}$ website views per year

At BMC, research is always in progress.

Learn more biomedcentral.com/submissions 